\title{
Memahami pengetahuan, sikap dan perilaku penggunaan alat pelindung diri petugas kebersihan di RSUD Dr. Zubir Mahmud, Kabupaten Aceh Timur
}

\author{
Khairil Fauzan ${ }^{1}$, dan Salianto ${ }^{2}$
}

\begin{abstract}
Occupational health and safety (OHS) is an important thing that must be applied in all workplaces, both in the formal and informal sectors. One thing that can be done to improve OHS is to use Personal Protective Equipment (PPE). Unfortunately, we often encounter many officers who rarely use PPE. The hypothesis proposed is that the use of PPE will increase if officers have positive knowledge and attitudes towards the use of PPE. This program employed quantitative analysis with a cross sectional approach. The data that had been collected were analyzed in the form of a frequency distribution. The population in this study were all cleaning service officers in dr. Zubir Mahmud East Aceh Regency, as many as 47 respondents. The result showed that there was a relationship between the knowledge and attitudes of cleaning service officers on health behavior and occupational safety about the use of PPE $(p<0.05)$. Suggestions for the hospital to update the insights of all hospital cleaning service officers by holding outreach and in the future it is expected to be able to recruit non-medical workers, especially cleaning services with certain standards, for example limiting the productive age with a minimum high school education standard so that cleaning service workers will digest more easily the socialization material presented and able to carry out safety behavior especially the use of PPE in proper and correct manner in every job.
\end{abstract}

\section{Keywords}

Knowledge, attitudes, occupational health and safety behaviour, personal protective equipment

\section{Pendahuluan}

Kesehatan dan Keselamatan Kerja (K3) merupakan hal penting yang harus diterapkan di semua tempat kerja, baik pada sektor formal maupun sektor informal. Terlebih bagi tempat kerja yang memiliki risiko atau bahaya yang tinggi, serta dapat menimbulkan Kecelakaan Akibat Kerja (KAK) dan Penyakit Akibat Kerja (PAK). Adapun KAK adalah kecelakaan yang berhubungan dengan hubungan kerja sedangkan Penyakit Akibat Kerja (PAK) yaitu penyakit yang didapat atau ditimbulkan pada waktu melaksanakan pekerjaan (Hedaputri et al., 2021).

Data dari international labour organization (ILO) (Sulhinayatillah, 2017) tahun 2013, menyebutkan bahwa setiap tahun terdapat lebih dari 250 juta kecelakaan di tempat kerja dan lebih dari 160 juta pekerja menjadi sakit akibat bahaya di tempat kerja. Setiap lima belas detik, satu pekerja di dunia meninggal karena Kecelakaan Akibat Kerja (KAK) sedangkan dalam waktu yang sama seratus enam puluh pekerja mengalami Penyakit akibat kerja (PAK). Tahun sebelumnya (2012) ILO mencatat angka kematian dikarenakan Kecelakaan Akibat Kerja (KAK) dan Penyakit akibat kerja (PAK) total sejumlah dua juta kasus (Sulhinayatillah, 2017).
Menurut pusat data dan informasi Kementerian Kesehatan Republik Indonesia (2015) (Yuantari \& Nadia, 2018) tentang situasi kesehatan kerja tahun 2015, jumlah kasus Kecelakaan Akibat Kerja yang terjadi antara tahun 20112014 adalah sebesar 92.453 kasus dengan jumlah kasus paling tinggi terjadi pada tahun 2013 yaitu sebesar 35.917 kasus. Sedangkan data untuk kasus Penyakit Akibat Kerja antara tahun 2011-2014 adalah 57.929 kasus tahun 2011, 60.322 kasus tahun 2012, 97.144 kasus tahun 2013, dan 40.694 kasus pada tahun 2014.

Salah satu tempat kerja yang berisiko adalah Rumah Sakit. Hal ini karena Rumah Sakit memiliki potensi terjadinya penyakit infeksi terhadap para karyawan, pasien, bahkan pengunjung. Dilihat dari jenis pekerjaan yang ada di Rumah Sakit, dapat dikatakan tenaga medis merupakan karyawan yang rentan terkena Penyakit Akibat Kerja (PAK), namun tenaga non medis juga memiliki potensi untuk terkena Penyakit akibat kerja (PAK), walaupun

\footnotetext{
1 Universitas Medan Area ${ }^{2}$ UIN Sumatera Utara
}

Korespondensi:

Khairil Fauzan, Fakultas Psikologi Universitas Medan Area

Email: khairilfauzan@staff.uma.ac.id 
mereka tidak melakukan kontak langsung dengan pasien. Salah satu tenaga non medis yang ada di Rumah Sakit adalah petugas kebersihan (cleaning service) (Warmuni \& Rusminingsih, 2020).

Petugas cleaning service adalah orang yang bertanggung jawab dalam tugas pemeliharaan dan pelayanan kebersihan di suatu tempat, perkantoran atau institusi baik pemerintah maupun swasta. Secara umum petugas cleaning service memiliki tugas membersihkan setiap ruangan yang ada di area Rumah Sakit seperti menyapu, mengepel, membersihkan kaca dan bagian yang berdebu atau kotor dan mengangkut sampah non medis yang ada di area Rumah Sakit (Ratnasari et al., 2016).

Berdasarkan observasi awal yang peneliti lakukan terhadap 5 petugas cleaning service RSUD dr. Zubir Mahmud terdapat 3 orang petugas cleaning service yang masih memiliki perilaku Kesehatan dan Keselamatan Kerja (K3) yang kurang baik seperti tidak memakai sarung tangan dan sepatu tertutup saat melakukan pekerjaan membersihkan area Rumah Sakit, dan 2 orang lagi yang sudah memiliki perilaku Kesehatan Dan Keselamatan Kerja (K3) yang baik dimana mereka sudah menerapkan penggunaan Alat Pelindung Diri (APD) dengan benar.

Padahal, bermacam tugas dan pekerjaan petugas cleaning service tentunya tidak terlepas dari risiko bahaya penyakit yang ditimbulkan dan mengganggu keselamatan dan kesehatan jiwa petugas. Oleh karena itu petugas harus memahami, mengerti, taat dan patuh menggunakan Alat Pelindung Diri (APD) dalam bekerja (Warmuni \& Rusminingsih, 2020).

Bahaya yang dapat mengancam petugas cleaning service Rumah Sakit antara lain terpapar debu yang dibersihkan, terpeleset saat mengepel lantai, kontak dengan bahan kimia yang digunakan untuk mengepel lantai, terpapar bahaya biologi saat membersihkan laboratorium atau ruangan yang mengandung virus dan bakteri, tertusuk benda tajam seperti jarum suntik saat mengelola limbah tajam, sehingga dapat tertular penyakit seperti Hepatitis dan HIV/AIDS. Selain itu, petugas kebersihan juga

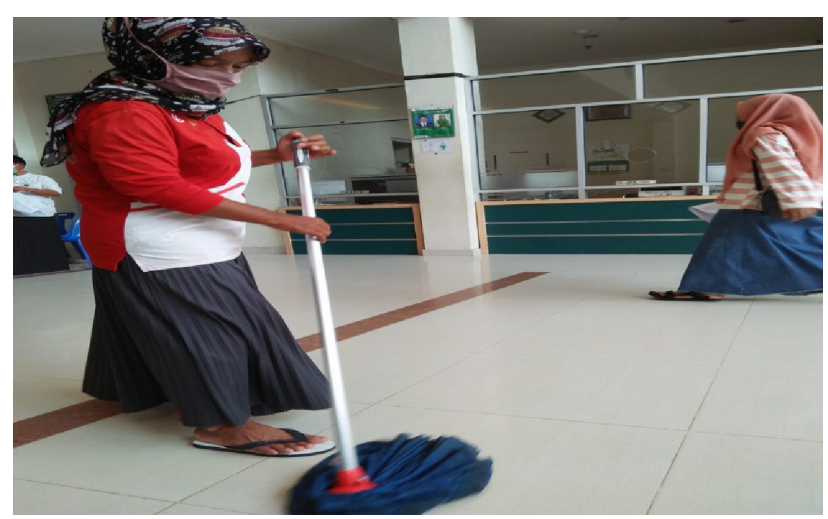

Gambar 1. Dokumentasi perilaku K3 penggunaan APD pada petugas kebersihan mitra berisiko terkena Penyakit Akibat kerja (PAK) seperti dermatitis kontak dan gangguan muskuloskeletal (Yuantari \& Nadia, 2018).

Petugas cleaning service di RSUD dr. Zubir Mahmud merupakan pekerja yang dikontrak langsung oleh pihak manajemen rumah sakit yang berjumlah 50 orang. Secara umum mereka memiliki tugas membersihkan setiap ruangan di area rumah sakit (inside), membersihkan halaman di area ruangan (outside) serta membersihkan kamar mandi pasien.

Berdasarkan penelitian (Agussamad, 2019) tentang faktor-faktor yang berhubungan dengan pencegahan infeksi pada petugas cleaning service di RSUD Langsa. Diketahui terdapat 7 orang pekerja tertusuk jarum yang salah satunya adalah pekerja yang tidak patuh terhadap penggunaan Alat Pelindung Diri (APD). Dari hasil wawancara singkat yang dilakukan pada 7 orang cleaning service, petugas mengatakan pernah tertusuk jarum 2 orang dan 5 orang lagi pernah mengalami penyakit kulit (gatal-gatal) pada saat membersihkan kamar mandi pasien. 6 dari 7 petugas diatas mengaku tidak mengetahui tentang pencegahan infeksi dengan baik (Agussamad, 2019).

Dilihat dari segi pengetahuan secara umum, petugas yang masih belum menjalankan pekerjaan sesuai dengan SOP yang berlaku menuturkan bahwa, meskipun sudah mengetahui tentang penggunaan Alat Pelindung Diri (APD) namun penggunaan APD masih di hiraukan pada saat mereka melakukan pekerjaan. Para petugas utamanya mengabaikan penggunaan sarung tangan dan masker.

Survey diatas selaras dengan penelitian yang dilakukan Bahar et al. (2019) tentang dimana pengetahuan yang minim dan sikap yang kurang adaptif terhadap APD menyebabkan minimnya penggunaan APD (Bahar et al., 2019). Adapun program pengabdian ini bertujuan untuk menginvestigasi secara empirik sejauh mana pengetahuan dan sikap terhadap penggunaan APD pada petugas kebersihan di institusi mitra. Hasil dari investigasi ini diharapkan dapat menjadi data rujukan yang valid dalam melaksanakan langkah atau kebijakan berikutnya oleh pihak manajemen mitra.

\section{Metode}

Saat melakukan kegiatan tim dosen mendapat Pengarahan Dari Tim PPI RSUD Dr. Zubir Mahmud untuk diskusi. Hal ini dilakukan agar terjadi kerjasama yang baik antara tim pengabdian dengan mitra serta mengantisipasi terjadinya kesalahpahaman di masa depan.

Desain penelitian yang digunakan dalam adalah kuantitatif dengan pendekatan Cross Sectional. Pengambilan data dilakukan di Rumah Sakit Umum Daerah (RSUD) dr. Zubir Mahmud yang berada di Jalan Medan-Banda Aceh Km. 372 Desa Seuneubok Barat Kec. Idi timur Kab. Aceh timur. Populasi dalam penelitian ini adalah seluruh Petugas cleaning service RSUD dr. Zubir Mahmud yang berjumlah 50 orang. Dikarenakan populasi sangat terbatas dan hanya berfokus pada cleaning service yang 
Tabel 1. Distribusi Frekuensi Perilaku Kesehatan dan Keselamatan Kerja (K3) tentang Penggunaan Alat Pelindung Diri (APD) pada Petugas cleaning service di RSUD dr. Zubir Mahmud Kabupaten Aceh Timur Tahun 2020

\begin{tabular}{lll}
\hline Perilaku K3 tentang APD & Frekuensi (f) & $(\%)$ \\
\hline Lengkap & 16 & 34 \\
Tidak Lengkap & 31 & 66 \\
\hline Jumlah & 47 & 100 \\
\hline
\end{tabular}

tidak bertugas di unit isolasi khusus dan cleaning service yang bertugas mengangkut sampah medis, maka penulis mendapat sebanyak 47 responden untuk penelitian ini. Analisis data yang dilakukan dalam penelitian ini adalah Analisis Chi-Square.

\section{Hasil}

Berdasarkan data dari 47 responden, usia mayoritas petugas adalah 41-50 tahun sebanyak 26 orang $(55,3 \%)$. Sisanya berusia 51-60 tahun (34\%) dan 31-40 tahun (11\%). Sedangkan mayoritas memiliki latar belakang pendidikan Sekolah Dasar (SD) sebanyak 39 responden $(82,9 \%)$, lalu SMP sebanyak 3 orang (6.3\%) dan SMA sebanyak 5 orang (11\%).

Berdasarkan tabel 1. diatas ditunjukkan bahwa dari 47 responden, mayoritas sebanyak 31 responden (66\%) tidak menggunakan APD secara lengkap. Data lain menunjukkan bahwa dari 47 responden terdapat 12 responden yang berpengetahuan baik, 16 responden yang berpengetahuan cukup dan ada 19 responden yang berpengetahuan kurang.

Sementara itu, hasil uji statistik Chi-Square (Pearson chi-square) pada derajat kepercayaan 95\% $(a=0,05)$ diperoleh nilai $p$-value $=0,000(\mathrm{p}<0,05)$ yang berarti $\mathrm{Ha}$ diterima dan Ho ditolak sehingga dapat disimpulkan bahwa ada pengaruh baik sikap dan pengetahuan petugas cleaning service terhadap perilaku Kesehatan Dan Keselamatan Kerja (K3) tentang penggunaan Alat Pelindung Diri (APD).

\section{Diskusi}

\section{Perilaku Kesehatan dan Keselamatan Kerja tentang Penggunaan Alat Pelindung Diri}

Hasil penelitian ini sejalan dengan penelitian yang dilakukan oleh Hedaputri et al. (2021) bahwa penerapan Kesehatan dan Keselamatan Kerja (K3) masih sangat rendah yaitu sebanyak 44,8\% (Hedaputri et al., 2021) Hal ini juga sejalan dengan penelitian penelitian Bahar et al. (2019) yang menunjukkan bahwa tindakan penggunaan Alat Pelindung Diri (APD) pada pekerja cleaning service sebanyak masih perlu peningkatan, yakni disana hanya sejumlah 52,9\%. Lebih sedikit dari separuh total pegawai yang diteliti (Bahar et al., 2019).
Peneliti berasumsi bahwa penggunaan Alat Pelindung Diri (APD) sebagai penerapan Kesehatan dan Keselamatan Kerja (K3) yang diterapkan oleh petugas cleaning service di RSUD dr. Zubir Mahmud masih rendah, hal ini ditandai dengan kurang lengkapnya Alat Pelindung Diri (APD) yang digunakan petugas cleaning service dalam menjalankan tugas. Padahal wilayah kerja para petugas itu sangat luas dan mengandung risiko kecelakaan kerja yang tinggi, yakni meliputi pembersihan setiap ruangan di area Rumah Sakit (inside), pembersihan halaman (outside) serta membersihkan kamar mandi pasien. Kurang lengkapnya APD yang digunakan oleh cleaning service juga berhubungan dengan usia responden yang mayoritas berusia 41-50 tahun dan pendidikan responden yang mayoritas berpendidikan Sekolah Dasar (SD) sehingga petugas cleaning service sering mengabaikan kelengkapan APD sebagai upaya Kesehatan dan Keselamatan Kerja (K3).

\section{Hubungan Pengetahuan Petugas cleaning service terhadap Perilaku Kesehatan dan Keselamatan Kerja}

Hasil penelitian ini sejalan dengan penelitian Hedaputri et al. (2021) yang menyatakan bahwa ada pengaruh yang signifikan antara pengetahuan (X1) terhadap Kesehatan dan Keselamatan Kerja (Y). Maka, terdapat pengaruh yang positif antara pengetahuan Kesehatan dan Keselamatan Kerja (K3) terhadap kesadaran berperilaku Kesehatan dan Keselamatan Kerja (K3) dengan bukti nilai t hitung $>\mathrm{t}$ tabel $(3,765>2,032)$. Sejalan dengan penelitian Bahar, et al. (2018) bahwa uji chi square mendapatkan hasil yaitu terdapat hubungan antara pengetahuan dengan tindakan penggunaan Alat Pelindung Diri (APD) dengan nilai $p=0,042$. Kesimpulan dari penelitian ini yaitu terdapat hubungan antara pengetahuan dengan tindakan penggunaan Alat Pelindung Diri (APD) pada pekerja cleaning service (Bahar et al., 2019).

Penelitian ini juga sejalan dengan penelitian Yana (2019) bahwa terdapat hubungan antara pengetahuan Kesehatan dan Keselamatan Kerja (K3) dengan kesadaran berperilaku Kesehatan dan Keselamatan Kerja (K3) di Laboratorium $(\mathrm{r}=0,482)$. Besarnya hubungan pengetahuan Kesehatan dan Keselamatan Kerja (K3) terhadap kesadaran berperilaku Kesehatan dan Keselamatan Kerja (K3) sebesar 23,21\% yang menunjukkan bahwa terdapat pengaruh yang positif antara pengetahuan Kesehatan dan Keselamatan Kerja (K3) terhadap kesadaran berperilaku Kesehatan dan Keselamatan Kerja (K3) (Yana, 2019).

Pengetahuan merupakan kemampuan untuk mengetahui dan menjabarkan informasi yang diperoleh dari hasil penglihatan dan pendengaran. Hasil penglihatan dan pendengaran diperoleh antara lain melalui belajar, media informasi baik cetak maupun elektronik dan pengalaman seseorang. Pengetahuan merupakan salah satu unsur penting dalam pembentukan tindakan seseorang karena suatu perilaku yang didasari oleh pengetahuan lebih 
langgeng dari pada perilaku yang tidak didasari oleh pengetahuan (Prilia, 2015).

Peneliti berasumsi bahwa ada keterkaitan antara pengetahuan dengan perilaku Kesehatan dan Keselamatan Kerja (K3) tentang penggunaan APD sehingga semakin rendah pengetahuan maka semakin kurang perilaku K3 penggunaan APD. Usia dan tingkat pendidikan mempengaruhi tingkat pengetahuan seseorang dimana sebagian besar responden berusia 41-50 tahun. Pekerja pada usia ini cenderung lebih sulit untuk menerima informasi ditambah lagi dengan tingkat pendidikan yang mayoritas berpendidikan Sekolah Dasar (SD). Minimnya kualitas sumber daya pada petugas kebersihan ini tentu sangat berpengaruh terhadap pengetahuan mereka dan pada akhirnya juga pada perilaku K3 penggunaan APD saat bekerja.

\section{Hubungan Sikap Petugas cleaning service terhadap Perilaku Kesehatan dan Keselamatan Kerja tentang Penggunaan APD}

Hasil penelitian menunjukkan bahwa dari 47 responden terdapat 17 responden yang bersikap positif, mayoritas lengkap menggunakan APD sebanyak 15 responden $(88,2 \%)$ sedangkan dari 30 responden yang bersikap negatif mayoritas tidak lengkap menggunakan APD sebanyak 29 responden $(96,7 \%)$. Hasil uji statistik Chi-Square (Continuity Correction) pada derajat kepercayaan $95 \%(a=0,05)$ diperoleh nilai $p$-value $=0,000$ $(\mathrm{p}<0,05)$ yang berarti Ha diterima dan Ho ditolak sehingga dapat disimpulkan bahwa ada pengaruh sikap petugas cleaning service terhadap perilaku Kesehatan dan Keselamatan Kerja (K3) tentang penggunaan Alat Pelindung Diri (APD).

Sejalan dengan penelitian Hedaputri et al. (2021) bahwa terdapat pengaruh positif sikap terhadap kesadaran berperilaku Kesehatan dan Keselamatan Kerja (K3) dengan bukti t hitung $>$ t tabel $(2,134>2,032)$ dan bukti $\mathrm{F}$ hitung $>$ F tabel $(23,093>3,28)$

Sikap merupakan reaksi dan respon yang masih tertutup dari seseorang atas suatu stimulus atau objek. Pengukuran sikap dapat dilakukan secara langsung dan tidak langsung, secara langsung dapat ditanyakan bagaimana pendapat atau perasaan responden terhadap suatu objek (Mamudi, 2016). Peneliti mengasumsikan bahwa peran sikap seorang akan menentukan bagaimana cara berperilaku termasuk dalam menggunakan APD secara lengkap sebagai upaya menerapkan Kesehatan Dan Keselamatan Kerja (K3). Salah satu faktor terbentuknya sikap, dikarenakan pengalaman pribadi dan kepercayaan responden bahwa perilaku penggunaan APD dapat mengurangi risiko terpapar oleh penyakit infeksi terutama pada masa pandemi covid-19.

\section{Kesimpulan}

Sebagai hasil akhir dari pengabdian ini, diuraikan kesimpulan bahwa terdapat pengaruh dari pengetahuan dan sikap petugas cleaning service terhadap perilaku Kesehatan dan Keselamatan Kerja (K3) tentang penggunaan Alat Pelindung Diri (APD) $(\mathrm{p}<0,05)$. Sebab itu, untuk meningkatkan kedisiplinan penggunaan APD maka perlu dilakukan program lanjutan berupa penyuluhan pengetahuan dan pengubahan sikap terhadap APD.

Adapun saran ditujukan kepada dua pihak secara khusus. Bagi rumah sakit untuk memperbaharui wawasan semua petugas cleaning service Rumah Sakit agar terus membiasakan diri dengan budaya (K3) yang lebih baik lagi dengan mengadakan sosialisasi mengenai penggunaan APD. Juga untuk kedepannya agar merekrut tenaga kerja non medis khususnya cleaning service dengan standar tertentu misalnya membatasi usia produktif dengan standar pendidikan minimal SMA. Dengan demikian diharapkan tenaga kerja cleaning service akan lebih mudah mencerna materi sosialisasi yang disampaikan, sehingga dapat meningkatkan pengetahuan dan merubah sikap petugas cleaning service dalam bekerja khususnya dalam menerapkan budaya keselamatan kerja dengan menggunakan APD secara lengkap.

Sedangkan, bagi institusi pendidikan agar terus menambah referensi mengenai perilaku K3 tentang penggunaan APD yang dapat digunakan bagi penelitian selanjutnya dan dijadikan bahan masukan untuk proses penerapan berpikir ilmiah dalam memahami dan menganalisis suatu masalah yang terjadi di lapangan serta untuk meningkatkan mutu pendidikan.

\section{Referensi}

Agussamad, I. (2019). Faktor-faktor yang berhubungan dengan kepatuhan perawat rawat inap dalam menggunakan alat pelindung diri di RSUD Langsa tahun 2019. Jurnal EDUKES: Jurnal Penelitian Edukasi Kesehatan 2(2), 8493. https://e-jurnal.stikesydb.ac.id/index.php/edukes/article/ view/63

Bahar, A. P. I., Kawatu, P. A., \& Adam, H. (2019). Hubungan antara pengetahuan dan sikap dengan tindakan penggunan alat pelindung diri pada pekerja cleaning service di RSUP Prof. Dr. Rd Kandou Manado. KESMAS, 7(5).

Hedaputri, D. S., Indradi, R., \& Illahika, A. P. (2021). Kajian literatur: hubungan tingkat pengetahuan kesehatan dan keselamatan kerja (k3) dengan kejadian kecelakaan kerja. CoMPHI Journal: Community Medicine and Public Health of Indonesia Journal, 2(1), 185-193. https://doi.org/ 10.37148/comphijournal.v2i1.27

Mamudi. I. (2016), Pengaruh pengetahuan k3 dan sikap terhadap kesadaran berperilaku k3 di bengkel pemesinan SMK Negeri 2 Yogyakarta. Skripsi, Universitas Negeri Yogyakarta.

Prilia, R. (2015) Pengaruh pengetahuan K3 dan sikap terhadap kesadaran berperilaku K3 di Lab. CNC dan PLC SMK Negeri 3 Yogyakarta. Skripsi, Universitas Negeri Yogyakarta. 
Puspita, L. (2010). Hubungan kepatuhan penggunaan alat perlindungan diri (apd) oleh karyawan terhadap angka kesakitan karyawan di PT. Anwid Graha Yogyakarta. FKIK (Ilmu Keperawatan), 5(5).

Ratnasari, N., Hardjanto, M. S., \& Darnoto, S. K. M. (2016). Hubungan antara beban kerja dengan kelelahan kerja pada petugas cleaning service di Rumah Sakit PKU Muhammadiyah Surakarta (Doctoral dissertation, Universitas Muhammadiyah Surakarta).

Sulhinayatillah, S. (2017). Faktor-faktor yang berhubungan dengan kejadian kecelakaan kerja pada karyawan bagian produksi di PT. PP London Sumatera Indonesia Tbk. Palangisang Crumb Rubber Factory Bulukumba tahun 2017 (Doctoral dissertation, Universitas Islam Negeri Alauddin Makassar).
Warmuni, N. M., \& Rusminingsih, N. K. (2020). Hubungan tingkat pengetahuan dengan kepatuhan pemakaian alat pelindung diri petugas cleaning service di Rumah Sakit Umum Bangli Tahun 2019. JURNAL KESEHATAN LINGKUNGAN (JKL), 10(1).

Yana, R. (2019). Hubungan pengetahuan k3 terhadap kesadaran berperilaku k3 pada mahasiswa di laboratorium. Indonesian Journal of Laboratory, 1(3), 46-50. https://doi.org/10.22146/ ijl.v1i3.48721

Yuantari, C., \& Nadia, H. (2018). Analis resiko keselamatan dan kesehatan kerja pada petugas kebersihan di rumah sakit. Faletehan Health Journal, 5(3), 107-116. https://doi.org/10. 33746/fhj.v5i3.20 